\title{
Manajemen Pelestarian Angklung sebagai Warisan Budaya Takbenda
}

\author{
Hana Yudiawati \\ Program Pascasarjana Institut Seni Indonesia Yogyakarta; \\ Jalan Suryodiningratan No.8, Yogyakarta - 55143 \\ E-mail: hanayudiawati73@gmail.com
}

\begin{abstract}
ABSTRAK
Indonesia merupakan negara yang kaya akan budaya dan alamnya. Perkembangan budaya di Indonesia sangatlah beragam, mulai dari rumah adat, upacara adat, tarian, lagu, musik, dan bentuk seni pertunjukan lainnya, yang menampilkan keunikan masing-masing nilai budaya setempat. Seperti yang akan diuraikan di sini adalah salah satu alat musik Indonesia yaitu angklung. Penelitian ini bertujuan untuk mengetahui manajemen pelestarian angklung dan sebagai studi kasus penelitiannya adalah musik angklung yang dikembangkan dan dilestarikan di sanggar seni Saung Udjo Bandung, yang merupakan pusat pelestarian dan pertunjukan kebudayaan tradisional Sunda. Untuk metode yang digunakan adalah metode deskriptif kualitatif yaitu metode penelitian yang memanfaatkan data untuk dijabarkan sesuai data yang dilihat dan terjadi di lapangan. Pengumpulan data dilakukan dengan cara observasi langsung, wawancara, dan studi literatur. Hasil analisis menghasilkan beragam bentuk manajemen pelestarian, yaitu: Di bidang produksi, angklung yang masih tetap dipertahankan pembuatan angklung oleh para perajin secara manual dengan menggunakan tangan; Di bidang lahan, masih memanfaatkan lahan bambu yang secara terus-menerus perlu menjaga tata cara dan teknik penebangannya sehingga tidak dianggap merusak lahan bambu yang ada; Di bidang pertunjukan, diselenggarakan kegiatan dan event pertunjukan angklung di berbagai daerah; Di bidang pendidikan, masuknya angklung pada pembelajaran ekstrakurikuler di sekolah, baik di tingkat Taman Kanak-kanak sampai Perguruan Tinggi. Terwujudnya pelestarian tentu diperlukan kolaborasi yang tepat dari pihak pemerintah maupun masyarakat Indonesia dan peran serta pemerhati seni perlu sejalan dalam menjaga pelestarian angklung.
\end{abstract}

Kata Kunci: manajemen, pelestarian, angklung warisan takbenda

\section{Conservation Management of Angklung as Intangible Cultural Heritage}

\begin{abstract}
Indonesia is a country rich in culture and nature. The development of culture in Indonesia is very diverse, ranging from traditional houses, traditional ceremonies, dances, songs, music, and other forms of performing arts, which show the uniqueness of each local cultural value. As will be described here is one of the Indonesian musical instruments, namely the angklung. This study aims to determine the management of angklung preservation. As a case study, the research is angklung music developed and preserved in the Saung Udjo Bandung art studio, a center for the preservation and performance of Sundanese traditional culture. The method used is a qualitative descriptive method, namely a research method that utilizes data to be described according to the data seen and occurs in the field. Data collection is done by direct observation, interviews, and literature studies. The results of the analysis resulted in various forms of conservation management, namely: In the field of angklung production, the craftsmen still made angklung by hand; In the field of land, it is still utilizing bamboo land which continuously needs to maintain the methods and techniques of cutting so that it is not considered as damaging the
\end{abstract}


existing bamboo land; In the field of performances, angklung performance activities and events are held in various regions; In the field of education, the inclusion of angklung in extracurricular learning in schools, both at Kindergarten to College levels. The realization of conservation certainly requires proper collaboration from the government and the Indonesian people. The participation of art observers needs to be in line with maintaining the preservation of angklung.

Keywords: management, preservation, intangible heritage angklung

\section{PENDAHULUAN}

\section{Latar Belakang}

Angklung merupakan salah satu alat musik tradisional yang berasal dari Jawa Barat, yang awal kehadirannya berfungsi sebagai sarana upacara ritual berhubungan dengan panen padi (Wiramihardja, 2010). Tetapi dalam perkembangannya, sekarang angklung berfungsi sebagai sarana hiburan bahkan untuk pendidikan sebagai pembentuk karakter bangsa.

Alat musik angklung dibuat dari bahan bambu pilihan berjenis bambu hitam atau bambu wulung. Bentuk angklung terdiri dari dua hingga empat buah tabung bambu dengan ukuran tertentu dan berbeda yang disesuaikan dengan nada yang dibutuhkan, dirangkai menjadi sebuah kesatuan, dan diikat dengan rotan. Suara yang unik timbul dari getaran tabung akibat digoyangkan oleh para pemain, sehingga musik angklung banyak digemari dan dalam perkembangan sekarang di setiap daerah di Indonesia banyak yang mengapresiasi.

Menurut sumber dari JPPI (Jaringan Pelestarian Pusaka Indonesia), angklung dapat dikatakan sudah menjadi identitas Indonesia. Tahun 2010 dalam konvensi UNESCO (Organisasi Pendidikan, Keilmuan, dan Kebudayaan PBB) pengukuhan angklung sebagai warisan budaya dunia dilakukan oleh UNESCO tepatnya pada tanggal 16 November 2010 di Nairobi, Kenya, Afrika Timur. Angklung ditetapkan sebagai "Representative List of the Intangible Cultural Heritage of Humanity" (Daftar Representatif Budaya Takbenda Warisan Manusia), The Intangible Heritage oleh UNESCO. Penetapan alat musik angklung ini menyusul wayang, keris, dan batik yang telah terlebih dulu ditetapkan sebagai warisan budaya dunia dari Indonesia (Jaringan Pelestarian Pusaka Indonesia (JPPI), 2003).

Indonesia sebagai salah satu negara yang mendapat perhatian UNESCO berkenaan dengan pelestarian budaya angklung yang sudah dikenal keberadaannya, baik di Indonesia bahkan ke mancanegara. Sebagai negara yang sudah meratifikasi Konvensi 2003 tersebut, Indonesia memiliki kewajiban untuk melindungi semua warisan budaya takbenda di Indonesia melalui indentifikasi, inventarisasi (pencatatan warisan budaya takbenda), penelitian, preservasi (menjaga dan memelihara), memajukan asal tidak tercerabut dari akar budayanya, 
mentransmisikan budaya melalui pendidikan usia dini (keluarga, kelompok bermain), pendidikan luar sekolah (sanggar, perkumpulan, kursus-kursus), dan pendidikan formal (pendidikan dasar sampai perguruan tinggi), serta melibatkan komunitas, kelompok sosial, dan perseorangan. Kesadaran untuk melestarikannya melalui transmisi budaya dari generasi ke generasi, karena salah satu fungsi dari angklung adalah sebagai wahana pembentuk karakter bangsa (Hermawan, 2013). Artinya dengan permainan angklung, ada unsur kerja sama dan saling menghormati di antara pemain, karena tidak semua dapat berbarengan membunyikan angklung yang mereka pegang, melainkan mereka membunyikan alat sesuai dengan partitur lagu, secara bergantian untuk membentuk keharmonisan suara yang dihasilkannya. Adanya kekompakan satu sama lain di antara para pemainnya akan terjalin rasa persatuan dan saling memperhatikan. Sama seperti apa yang dikatakan oleh Somawijaya (1995) yang mengatakan karena sifat kolaboratif musik angklung, maka dalam memainkan alat musik ini perlu kerja sama, rasa saling menghormati di antara para pemain, bersama dalam disiplin, tanggung jawab, konsentrasi, pengembangan imajinasi, dan kolaborasi untuk bermain melodi.

Wiramihardja mengatakan bahwa pada awalnya angklung merupakan salah satu alat bunyi-bunyian yang digunakan untuk upacara-upacara yang berhubungan dengan padi. Angklung tidak digunakan sebagai kesenian murni, melainkan sebagai kesenian yang berfungsi dalam kegiatan kepercayaan (Wiramihardja, 2010). Kesenian angklung dipertahankan karena membuat masyarakat kohesif dan kondusif, merasa senasib sepenanggungan, menumbuhkan ikatan emosional dan perasaan primordial, dan membuat solid hubungan di dalamnya (Azhari, 2007).

Pada kacamata para seniman, memandang angklung itu mampu mengikuti perkembangan zaman dan bahkan diakui di berbagai negara sebagai alat musik yang berkelas dan mempunyai nilai seni yang tinggi (Raharjo, 2014). Walaupun keberadaan seni angklung sekarang ini masih berkembang terus, baik secara fungsi, bahan, teknik permainan, bentuk pertunjukannya, tetapi kita tidak boleh lengah. Tantangan dalam upaya pelestarian, khususnya kesenian tradisional angklung semakin berat, karena perkembangan zaman serta adanya arus globalisasi. Semakin majunya arus globalisasi, rasa cinta terhadap kesenian sendiri semakin berkurang dan ini sangat berdampak kurang baik untuk masyarakat Indonesia. Maka dari itu, perlu adanya suatu konsep pelestarian dan pengelolaan yang berkelanjutan dan perhatian, baik dari masyarakat, pemerintah daerah, maupun pemerintah pusat. Diperlukan manajemen untuk dapat mengelola angklung yang ada di berbagai daerah di Indonesia.

Berdasarkan latar belakang di atas, maka rumusan masalah yang timbul adalah bagaimana bentuk manajemen yang dilakukan masyarakat dan pemerintah 
dalam upaya melestarikan angklung. Dengan begitu tujuan penelitiannya adalah untuk mengetahui usaha apa saja yang dilakukan oleh masyarakat ataupun pemerintah dalam mengelola pelestarian angklung. Harapannya dengan hasil penulisan ini selain dapat bermanfaat untuk masyarakat luas, juga kita perlu lebih peduli dan meningkatkan perhatian terhadap seni-seni tradisi milik bangsa untuk tetap dipertahankan dan dilestarikan keberadaannya supaya tidak sampai punah.

\section{Kajian Pustaka}

\section{Manajemen}

Menurut R.Terry (2013), manajemen dapat didefinisikan sebuah proses dari berbagai tindakan, seperti perencanaan, pengorganisasian, pelaksanaan, dan pengawasan. Manajemen sangat penting bagi setiap aktivitas individu atau kelompok dalam organisasi untuk mencapai tujuan yang diinginkan. Manajemen berorientasi pada proses (process oriented) yang berarti bahwa manajemen membutuhkan sumber daya manusia, pengetahuan, dan keterampilan agar aktivitas menjadi lebih efektif atau dapat menghasilkan tindakan dalam mencapai kesuksesan. Oleh sebab itu, tidak akan ada organisasi yang akan sukses apabila tidak menggunakan manajemen yang baik.

Menurut Hasibuan, Mulayu (2002), manajemen adalah ilmu dan seni, mengatur proses pemanfaatan sumber daya manusia dan sumber-sumber lainnya secara efektif dan efesien untuk mencapai suatu tujuan. Dari beberapa pengertian manajemen di atas, apabila diterapkan dalam pembahasan yang dimaksud dengan manajemen adalah ilmu mengatur proses untuk mencapai tujuan yang telah ditetapkan sebelumnya untuk mencapai hasil yang sesuai.

\section{Pelestarian}

Menurut Asworth (1991) pelestarian merupakan manajemen perubahan. Di sini lebih tepat penerapannya, karena sesuatu dapat dilestarikan tentunya berdasarkan pengelolaan atau manajemen yang direncanakan. Tidak ada pelestarian suatu barang atau tempat atau lingkungan tanpa adanya perancangan dan gagasan. Sesuatu bentuk kegiatan yang dilakukan secara terus-menerus tentu dirancang terlebih dahulu. Maka, pengertian dari pelestarian sama halnya dengan pengelolaan secara terus-menerus sesuai dengan tujuan yang diinginkan.

Menurut Mashuri (2011) pelestarian adalah upaya pengelolaan pusaka melalui kegiatan penelitian, perencanaan, perlindungan, pemeliharaan, pemanfaatan, pengawasan, atau pengembangan secara selektif untuk menjaga kesinambungan, keserasian, dan daya dukungnya dalam menjawab dinamika zaman untuk membangun kehidupan bangsa yang lebih berkualitas. Dengan penelitian ini telah mengibaratkan tentang arti pelestarian dalam pelaksanaannya tidak akan terlepas dari suatu pengelolaan. 
Seperti pada piagam Jaringan Pelestarian Pusaka Indonesia (JPPI) (2003) juga mengartikan pelestarian adalah upaya pengelolaan pusaka melalui kegiatan penelitian, perencanaan, perlindungan, pemeliharaan, pemanfaatan, pengawasan, dan/atau pengembangan secara selektif untuk menjaga kesinambungan, keserasian, dan daya dukungnya dalam menjawab dinamika zaman untuk membangun kehidupan bangsa yang lebih berkualitas. Hampir mirip dengan yang dikatakan Adhishakti bahwa pelestarian (konservasi) pusaka bukanlah romantisme masa lalu namun justru membangun masa depan yang menyinambungkan berbagai potensi masa lalu dengan perkembangan zaman yang terseleksi.

\section{Pusaka Saujana}

Menurut Tim Penyusun Kamus Pusat Bahasa (2005) pusaka berarti heritage (Bahasa Inggris). Perkembangan pemahaman pusaka yang awalnya bertumpu pada artefak tunggal, namun telah meluas, di mana salah satu pengertian saujana adalah merefleksikan tata cara masyarakat dalam mengolah lahan dan sumber daya alam yang berkelanjutan. Banyak saujana merefleksikan keberadaan dan perkembangan masyarakat lokal dalam mengelola sistem lingkungannya dalam waktu yang lama, sehingga tercapai keharmonisan hidup dengan alam dan terpelihara identitas budaya masyarakat. Dapat diartikan, saujana merupakan fenomena kompleks dengan identitas pusaka yang ragawi (tangible) dan bukan ragawi (intangible). Angklung yang merupakan intangible heritage semakin menyadarkan kita semua akan kekayaan budaya Indonesia. Juga mampu menumbuhkan rasa bangga dan cinta pada budaya bangsa Indonesia terutama angklung.

Menurut Masunah, Juju (2003) mengatakan bahwa instrumen angklung disebut sebagai instrumen pusaka karena bunyinya yang dipercaya dapat mendatangkan dewi padi atau Dewi Sri. Upacara persembahan dan penghormatan kepada Dewi Sri merupakan bentuk dari kepercayaan masyarakat Sunda kuno.

\section{METODE PENELITIAN}

Guna mencapai tujuan penelitian, dibutuhkan suatu metode untuk mendapat informasi yang benar-benar dimengerti dan hasilnya sesuai dengan yang diharapkan. Penelitian ini menggunakan pendekatan kualitatif dan data yang dihasilkan bersifat deskriptif (Sugiyono, 2011). Dalam hal ini sumber buku merupakan awal informasi yang penulis gunakan untuk mencari data terkait objek penulisan. Teknik pengumpulan datanya dilakukan dengan observasi langsung, wawancara, dan studi literatur. Observasi secara langsung sebagai studi kasus adalah dengan mengunjungi lokasi Saung Angklung Udjo (SAU) Padasuka 
Bandung Jawa Barat, pada tanggal 26 September 2020. Pada wawancara atau interview ini, penulis secara langsung mewawancarai Ibu Eli (bagian pemasaran SAU) dan Kang Nandar (perajin angklung). Tujuan penulis mengadakan wawancara adalah untuk mendapatkan keterangan secara objektif dan menguatkan argumen atau sumber sebelumnya yang telah penulis dapatkan. Tidak ketinggalan sebagai narasumber utama terkait data angklung sebagai warisan takbenda dunia ini didapatkan dari Dosen Tata Kelola Seni, Program Pascasarjana Institut Seni Indonesia Yogyakarta, yaitu Ibu Laretna T. Adishakti pada saat kuliah Seni dan Pusaka.

Untuk studi literatur, sumbernya penulis peroleh dari hasil studi, jurnal, artikel, publikasi ilmiah, maupun buku eletronik dilakukan dengan mesin pencari sekunder yang digunakan: scribd.com, epdf.pub, pdfdrive.net, dan google.com. Pencarian dilakukan pada bulan September sampai bulan November 2020. Bentuk analisis media digunakan untuk memanfaatkan dokumen yang ada di media populer di mana penulis dapat melihat apa yang orang-orang lain tulis terutama mengenai seni angklung. Setelah seluruh data terkumpul, kemudian dipilah, dipilih, dan direduksi sebelum ditarik benang merah yang mengarah pada kesimpulan.

\section{HASIL DAN PEMBAHASAN}

Menurut sejarahnya, kata "angklung" sendiri berasal dari dua kata bahasa Sunda, yaitu “angkleung-angkleung” yang berarti barang yang diapungapung dan "klung" yang berarti suara dari alat musik tersebut. Jadi, angklung berarti suara yang dihasilkan dengan cara diangkat atau diapung-apungkan (Astuti, 2020). Pada awalnya angklung disajikan untuk kegiatan yang bersifat arak-arakan yang berhubungan dengan panen padi.

Instrumen angklung sebenarnya memiliki sejarah panjang terkait dengan masyarakat Badui, di mana permainan kesenian angklung buhun sangat sakral. Buhun dalam masyarakat setempat berarti tua. Dalam bahasa Sunda lain disebut baheula atau zaman dahulu. Angklung buhun berarti angklung tua atau angklung peninggalan. Angklung buhun tidak hanya mencerminkan rasa seni masyarakat Badui, tetapi juga nilai-nilai spiritual dan pergelaran angklung ini tidak dapat dilaksanakan setiap saat. Bagi masyarakat Badui, angklung buhun merupakan bagian dari ritual sehingga memiliki unsur magis yang kental. Jenis kesenian ini kemudian menyebar dan tumbuh di lingkungan masyarakat pedesaan di Jawa Barat (Supriyadi, 2006). 


\section{A. Keberadaan Musik Angklung}

Keberadaan angklung telah mengalami berbagai perubahan yang telah dilalui mulai dari perubahan bentuk, fungsi, sampai pada perubahan nada. Demikian pula berbagai situasi telah dilaluinya, bahkan kesenian ini sempat mengalami keterpurukan pada awal abad ke-20. Namun seiring berjalannya waktu, diprakarsai oleh Daeng Sutigna, seniman tradisi Sunda yang mengenalkan pertama kali tahun 1938, angklung memakai tangga nada diatonis, sehingga masyarakat umum lebih mudah menerima dan menikmatinya. Perubahan dari nada pentatonis daminatila, berubah menjadi memakai nada diatonis solmisasi. Untuk pertunjukan yang ditampilkannya, kalau dulu dilakukan secara arak-arakan, sekarang dipertontonkan pada panggung pertunjukan (wawancara Eli, 2020).

Untuk perubahan bentuk angklung misalnya, dapat dilihat dari batang penyangganya tinggi/panjang (bentuk angklung arak-arakan Badui), sekarang batangnya seimbang disimetriskan dengan tabung yang mengeluarkan suara. Semula bentuk angklungnya tinggi, menjadi lebih pendek dan atas tabung berubah diberi kayu sebagai penguatnya, dan untuk pembuatan angklung ini sampai sekarang tetap dipertahankan secara manual, sehingga para perajin angklung di daerah-daerah tidak kehilangan mata pencaharian. Untuk bahan yang digunakan masih sama seperti dulu, masih ada yang dibuat dari bambu kuning dan bambu hitam.

Adanya perubahan yang awalnya berfungsi sebagai sarana ritual, kemudian berfungsi sebagai sarana penyambutan tamu, dan lebih luas lagi sebagai sarana pendidikan. Angklung juga sering dipakai untuk jamuan diplomat pada berbagai konferensi internasional. Sifat suaranya yang merdu dan alami, dan kebolehan memainkan lagu dari negara manapun di dunia, turut menciptakan suasana ramah dan kondusif. Sebagai sarana pendidikan, selain di Jawa Barat khususnya, ditemukan juga di beberapa daerah seperti di Yogyakarta, Solo, Semarang, Sulawesi Selatan, di mana angklung menjadi seni yang dipelajari pada kegiatan ekstrakurikuler sekolah. Terutama banyak ditemukan di tingkat Taman Kanak-kanak dan Sekolah Dasar.

Perkembangan selanjutnya di beberapa daerah lahir alat musik sejenis angklung seperti di daerah Bali dengan nama angklung rindik berfungsi sebagai iringan musik "Joget Bumbung". Namun dalam perkembangannya, sekarang sering dipakai untuk pelengkap acara pernikahan dan penyambutan tamu. Alat ini bernada slendro, dibunyikan dengan cara dipukul. Di Banyuwangi, Jawa Timur, ada angklung yang terkenal namanya angklung caruk, yaitu menyajikan dua kelompok musik angklung yang saling beradu keahliannya untuk bisa dinikmati para penonton. Berfungsi untuk mengiringi berbagai tarian yang dikolaborasikan dengan permainan saron, slenthem dan gong. Di Jawa Tengah juga ada angklung dengan nama angklung banyumasan, yang berlaras slendro, dibunyikan dengan 
cara digoyang. Aransemen yang ditampilkan berupa gendhing-gendhing Banyumasan, lagu-lagunya berkarakter aksen ngapak (Ensiklopedia Jakarta, 2019). Seperti contoh di Kota Yogyakarta, di setiap sudut jalan banyak dijumpai kelompok angklung Banyumasan, ini sudah menandakan bahwa generasi muda secara tidak langsung telah ikut melestarikan angklung.

\section{B. Pengukuhan Angklung menjadi Warisan Budaya Dunia}

Memang tidak gampang pemerintah dalam berupaya menjadikan angklung diakui dunia. Berdasarkan analisis, angklung memenuhi kriteria sebagai warisan budaya takbenda dunia antara lain karena angklung merupakan bagian penting identitas budaya masyarakat di Jawa Barat dan Banten. Seni musik ini mengandung nilai-nilai dasar Indonesia, saling menghormati dan keharmonisan social (wawancara Eli, 2020). Angklung sebagai warisan takbenda yang perlu dilestarikan keberadaannya secara terus-menerus oleh masyarakat Indonesia.

Adanya Badan Pelestarian Pusaka Indonesia disingkat BPPI (Indonesian Heritage Trust) adalah sebuah organisasi masyarakat berbentuk perkumpulan yang dibentuk oleh berbagai organisasi pelestarian daerah yang selalu berupaya melakukan langkah-langkah penyelamatan pusaka alam dan budaya yang terancam punah, menyiapkan masukan untuk kebijakan dan strategi pemerintah, serta memperkuat mekanisme pelestarian.

Keberadaan BPPI yang anggotanya tersebar di berbagai daerah di wilayah Indonesia, secara tidak langsung ikut berperan penting dalam dikukuhkannya angklung sebagai warisan dunia milik Indonesia. Ini sebagaimana yang dikatakan oleh Adishakti bahwa BPPI dengan jejaring sosial yang sudah terbentuk cukup kuat di berbagai daerah, telah menyatukan ide, gagasan, pemikiran, dan tujuan yang diharapkan sesuai dengan visi misi yang ada. Ditambah lagi saat temu pusaka dan Kongres BPPI yang diselenggarakan di Kota Bandung pada bulan September 2010, menjadi perhatian lebih, terutama manakala dikenalkannya permainan kesenian tradisional Sunda di Saung Angklung Udjo, semakin menambah kekaguman kita sebagai penikmatnya (wawancara Adishakti, 2020).

Dengan diakuinya angklung sebagai The Intangible Heritage, khususnya masyarakat Jawa Barat dan umumnya pencinta seni angklung di seluruh daerah di Indonesia, tanpa disadari telah terbius untuk lebih mengakui keberadaan angklung. Awalnya menganggap biasa saja menjadi luar biasa dan merasa bangga mempunyai alat musik angklung. Ini dikuatkan dari hasil wawancara dengan Kang Nandar salah seorang karyawan sekaligus perajin angklung di Saung Udjo, yang mengatakan:

"Urang mah reueus pisan angklung parantos dinobatkeun salah sahiji warisan budaya dunia teh...kukituna komo masyarakat Sunda umumna tangtos bangga tur bagja angklung bisa diakui dunia. 
Kukituna, sapertos abdi dugika danget ieu ngadamel angklung sanes kanggo nyukupi hirup wae, nanging ngaraos kagugah rasa kanggo ngiringan sasarengan miboga, micinta kanggo ngalestarikan seni warisan karuhun Sunda" (wawancara Nandar, 2020).

Dari penjelasan tersebut artinya bahwa Kang Nandar pribadi kagum dan bangga setelah angklung dikukuhkan sebagai warisan budaya dunia. Apalagi masyarakat Sunda secara umum pasti merasa bangga angklung telah diakui dunia. Untuk itu Kang Nandar sampai sekarang membuat angklung bukan saja untuk melangsungkan hidup untuk keluarga, tetapi tergerak untuk bisa terus melestarikan angklung sebagai warisan leluhur. Artinya banyak cara untuk mengelola atau melestarikan angklung, bentuknya dapat berupa menyenangi kekhasan suara yang dibunyikannya, mengapresiasi pertunjukan angklung, dan terjun berperan dalam membuat alat angklung sendiri.

Ada prinsip yang mungkin ini mendasari angklung dikukuhkan UNESCO, salah satunya data yang didapatkan penulis dari hasil wawancara dengan Eli (Bagian Pemasaran SAU) yang mengatakan bahwa melihat para wisatawan yang datang ke Saung Udjo dan pernah beberapa dari mereka (wisatawan dari negara Thailand, Jepang, Belanda) beranggapan bahwa di negaranya angklung banyak yang sudah kenal, latar belakang mereka menyenangi angklung itu adalah permainannya sangat mudah, menarik, mendidik, dan alatnya murah untuk dibeli (wawancara Eli, 2020). Pernyataan tersebut seringkali didengar dari para wisatawan mancanegara, ini setidaknya memberi gambaran bahwa angklung dapat dikenal luas karena angklung berbeda, banyak yang menarik perhatian mereka dari angklung ini, sehingga wajar saja PBB melalui UNESCO mengukuhkan angklung sebagai warisan takbenda dunia milik Indonesia yang perlu dilestarikan keberadaannya.

Salah satu peran yang perlu diakui kita bersama juga adalah keberadaan Saung Angklung Udjo sangat berkontribusi terhadap dikukuhkannya angklung sebagai warisan budaya dunia. Hal ini dapat dibuktikan dengan seringnya tim kesenian Saung Angklung Udjo tampil di beberapa negara sebagai ajang promosi agar angklung dapat mendunia dan dikenal lebih luas lagi. Dengan begitu, keberlangsungan segala bentuk kegiatan tim kesenian SAU tampil di luar negeri, setidaknya berpengaruh besar pada penilaian UNESCO.

\section{Pengelolaan Angklung Saung Udjo}

Seperti yang diterangkan di atas, bahwa sebagai studi kasus penelitian di sini adalah keberadaan angklung yang dikelola di Saung Udjo. Bagi masyarakat Bandung khususnya Jawa Barat, tidak asing dengan Saung Udjo yang merupakan stakeholder yang memiliki peranan besar bagi perkembangan angklung. Pemerintah Indonesia dan bahkan internasional pun banyak memberikan apresiasi 
atas kerja keras SAU untuk terus melakukan peningkatan daya guna terhadap pelestarian seni angklung.

Udjo Ngalagena yang dikenal sebagai tokoh yang mengembangkan angklung dan mengajarkannya pada banyak orang. Pertama kali pada tahun 1966, beliau pula yang mendirikan Saung Angklung Udjo yang secara sederhana di halaman rumahnya. Dengan luas tanah yang sedikit, akhirnya Saung atau saat itu disebut Sanggar Udjo, lambat laun mulai berkembang dan dengan perhatian dari Pemerintah Kota Bandung, dibangunlah beberapa tempat sebagai perluasan Saung Angklung Udjo (wawancara Eli, 2020).

Berbicara arti pelestarian seni angklung, tidak akan terlepas dari suatu bentuk pengelolaan. Berbagai proses pengelolaan, mulai dari perencanaan, pengorganisasian, pelaksanaan/pengarahan, dan evaluasi semua kegiatan di Saung Udjo dapat dikatakan sudah tertata cukup baik. Seperti adanya sarana pendukung atau fasilitas yang lengkap, seperti gamelan slendro, arumba, tempat belajar, dan gedung pertunjukan yang layak. Sebagai contoh lagi seperti suatu rangkaian pertunjukan angklung yang sudah tertata rapi, mulai dari opening, dibuka oleh MC, diterangkannya sejarah angklung, pertunjukan wayang, pentas helaran, angklung orkestra, tari Cirebon, bermain dan belajar angklung bersama semua penonton, dan diakhiri dengan sesi foto-foto, semua rangkaian tersebut menjadi ciri khas tersendiri dan menjadi kelebihan di Saung Udjo. Wisatawan dalam negeri maupun mancanagara selalu akan membawa kesan tersendiri setelah mengunjungi Saung Udjo.

Penampilan angklung di SAU yang dikolaborasi dengan berbagai alat musik lainnya menjadi kedinamisan tersendiri di hati penonton. Apalagi bentuk pameran yang dihidangkan setiap harinya, mulai dari aksesori, kaligrafi, kerajinan tangan, dan lain sebagainya, yang dikemas sedemikian rupa menjadi sesuatu yang sangat berkesan bagi para pengunjung. Yang menarik lagi SAU menjadi salah satu tempat wisata di Bandung di mana setiap pengunjung dapat melihat sendiri proses pembuatan angklung yang dipraktikkan oleh beberapa perajin. Saung Udjo sebagai jembatan kecil menuju gerbang industri budaya kreatif dunia dan Saung Udjo bisa memberikan berbagai kontribusi bagi masyarakat banyak (Setiawan, 2017).

\section{Upaya Manajemen Pelestarian Angklung}

Secara luas, manajemen dalam tulisan ini ditujukan pada bagaimana upaya pemerintah kita dalam mengatur, mempertahankan, dan mengembangkan angklung untuk tetap terus bertahan keberadaannya, sehingga tidak akan tergerus oleh arus perkembangan zaman. Karena banyak juga seni musik yang ada di Indonesia lambat laun menghilang dan tidak dikenal oleh generasi muda selanjutnya. Di sini pemerintah perlu berusaha melestarikan angklung sebagai 
bentuk konkrit untuk melindungi seluruh aset kekayaan budaya Indonesia dan menjadi upaya melestarikan serta menjaga kekayaan budaya Indonesia.

Dari hasil pengamatan penulis, dan juga hasil studi literatur, ada beberapa usaha masyarakat dan pemerintah Indonesia dalam mengatur keberlangsungan angklung tetap lestari, di antaranya:

- Dikembangkan dan dibangunnya rumah angklung oleh Pemerintah Daerah Jawa Barat sebagai sentra kegiatan pelestarian angklung yang bertempat di Saung Udjo.

- Menggalakkan cinta angklung, dengan rutinitasnya digelar pertunjukan angklung di berbagai daerah.

- Dimasukkannya angklung pada kurikulum sekolah sebagai bagian dari pelajaran mulok (khusus di Jawa Barat).

- Mendukungnya angklung dikenalkan pada dunia pendidikan sebagai pelajaran ektrakurikuler.

- Promosi dalam bentuk 'House of Angklung' diselenggarakan di Amerika.

Untuk upaya-upaya tersebut senantiasa tetap dipertahankan untuk menjaga eksistensi dari pelestarian angklung dan ini juga merupakan bentuk apresiasi kita kepada budaya lokal yang sudah diakui oleh dunia untuk dapat kita lestarikan dan pertahankan. Ini tidak menutup kemungkinan kalau kita tidak aktif maka, piagam UNESCO ini bisa dipertimbangkan kembali, masyarakat dan pemerintah tidak lagi menaruh perhatian pada "Angklung sebagai salah satu identitas budaya nasional". Artinya di sini bahwa seni angklung atau lebih tepatnya disebut musik angklung, sudah menjadi ciri khas dari bangsa kita yang sekarang banyak dipelajari di berbagai daerah di Indonesia maupun di mancanegara.

Sementara hasil analisis pengamatan langsung di lokasi dan dikuatkan dari hasil wawancara dengan pegawai di Saung Udjo yaitu Ibu Eli, penulis dapat simpulkan bahwa teknik pengelolaan organisasi seni angklung di sini sudah baik dan layak dicontoh. SAU sekarang dijadikan sebagai wisata sejarah musik di mana setiap pengunjung dapat melihat proses pembuatan angklung hingga menyaksikan aksi panggung bermain angklung yang dipentaskan pada setiap minggunya.

Hasil analisis tentang bagaimana pengelolaan Saung Udjo dalam upaya pelestarian angklung, di antaranya:

- Tetap dipertahankannya pembuatan angklung secara manual.

- Konsistennya para pemasok angklung untuk mempertahankan keberlangsungan Saung Udjo.

- Selalu siap memenuhi kebutuhan pasar internasional dalam hal kerajinan tangan sebagai suvenir. 
- Siap sedia setiap waktu untuk tampil sesuai jadwal yang sudah direncanakan.

- Promosi yang kontinu lewat jejaring sosial.

Dengan demikian perlu adanya kerja sama pihak pemerintah daerah dalam jaringan website yang luas, serta diperlukan adanya campur tangan pencinta seni angklung untuk bisa mempromosikannya (Aditya, Gratianus Tedjasendjaja1, 2015).

\section{KESIMPULAN}

Angklung yang ada di Indonesia sampai sekarang masih terus dilestarikan oleh semua lapisan masyarakat. Upaya pemerintah Indonesia untuk terus berusaha melestarikan angklung, merupakan bentuk konkrit untuk melindungi seluruh aset kekayaan budaya Indonesia dan menjadi upaya melestarikan serta menjaga kekayaan budaya Indonesia.

Hasil pengamatan selama penelitian, baik melalui observasi langsung ke Saung Angklung Udjo sebagai objek yang diteliti langsung, maupun melalui data pustaka terdahulu, beberapa usaha-usaha masyarakat, stakeholder, pemerintah pusat dan daerah dalam melestarikan angklung, yaitu: Dikembangkan dan dibangunnya rumah angklung oleh Pemerintah Daerah Jawa Barat sebagai sentra kegiatan pelestarian angklung yang bertempat di Saung Udjo; Menggalakkan cinta angklung, dengan rutinitasnya digelar pertunjukan angklung di berbagai daerah; Mendukungnya angklung dikenalkan pada dunia pendidikan sebagai pelajaran ektrakurikuler; Promosi dalam bentuk 'House of Angklung' diselenggarakan di Amerika; Tetap dipertahankannya pembuatan angklung secara manual; Konsistennya para pemasok angklung untuk mempertahankan keberlangsungan Saung Udjo; Selalu siap memenuhi kebutuhan pasar internasional dalam hal kerajinan tangan sebagai suvenir; Promosi yang kontinu lewat jejaring sosial.

Bentuk kepedulian dan pengelolaan pemerintah lainnya terhadap keberadaan angklung ini juga dapat dibuktikan dengan proses pembelajaran angklung yang diadakan secara formal dan nonformal; seperti yang bersifat formal di sekolah mulai dari tingkat Taman Kanak-kanak sampai Perguruan Tinggi. Adapun yang bersifat nonformal dalam pengelolaannya pemerintah setempat sering mengadakan kursus-kursus atau pelatihan-pelatihan untuk sanggar-sanggar seni maupun kelompok/organisasi atau instansi lainnya.

Indonesia memiliki kewajiban untuk melindungi semua warisan budaya takbenda di Indonesia melalui identifikasi, inventarisasi (pencatatan warisan budaya takbenda), penelitian, preservasi (menjaga dan memelihara), memajukan asal tidak tercerabut dari akar budayanya, mentransmisikan budaya melalui 
pendidikan usia dini (keluarga, kelompok bermain), pendidikan luar sekolah (sanggar, perkumpulan, kursus-kursus), dan pendidikan formal (pendidikan dasar sampai perguruan tinggi), serta melibatkan komunitas, kelompok sosial, dan perseorangan. Kesadaran untuk melestarikannya melalui transmisi budaya dari generasi ke generasi, untuk terus berjuang agar angklung ini tetap lestari. Pentingnya mencintai warisan budaya sendiri dan generasi muda khususnya, disadarkan untuk lebih bangga dan cinta pada budaya bangsa Indonesia.

Semua pemangku kepentingan, yakni Pemerintah Pusat, Pemerintah Provinsi, Pemerintah Kabupaten/Kota, dan masyarakat Indonesia perlu berupaya melakukan langkah-langkah penyelamatan pusaka alam dan budaya yang terancam punah; menyiapkan masukan untuk kebijakan dan strategi pemerintah; serta memperkuat mekanisme pelestarian. Perjuangan Indonesia untuk mendapatkan pengakuan dari UNESCO juga tidak sebatas menghindari adanya klaim dari bangsa lain, melainkan juga menghindari adanya protes bangsa lain terhadap apa yang dimiliki Indonesia.

\section{KEPUSTAKAAN}

Astuti, D. (2020). Sejarah Angklung, Alat Musik yang diakui Dunia. www.goadnewsfromindonesia.id

Ashworth, G. (1991). Heritage Planning: Conservation as management of change. Netherlands: Geo Press.

Azhari, A. (2007). Jago Main Angklung. Jakarta: Laskar Aksara.

Ensiklopedia Jakarta. (2019). Angklung Paglak Seni Musik. http://encyclopedia.jakarta-tourism.go.id/

Hasibuan, Malayu, S. P. (2002). Manajemen Sumber Daya Manusia. Jakarta: PT Bumi Aksara.

Hermawan, D. dkk. (2013). Angklung Sunda Sebagai Wahana Industri Kreatif dan Pembentukan Karakter Bangsa. Jurnal Seni \& Budaya Panggung, Volume 23, No. 2.

Jaringan Pelestarian Pusaka Indonesia (JPPI). (2003). Indonesia Charter for Heritage Conservation Jakarta Indonesia.

Mashuri. (2011). Konsep Pelestarian Pusaka Saujana di Kawasan Lembah Bada. https://doi.org/Teliti.com

Masunah, Juju, dkk. (2003). Angklung di Jawa Barat: Sebuah Perbandingan Buku 2. Bandung: Pusat Penelitian dan Pengembangan Pendidikan Seni.

R.Terry, G. (2013). Prinsip-prinsip Manajemen. Jakarta: PT Bumi Aksara.

Raharjo, E. (2014). Kajian Bentuk Pertunjukan Seni Angklung Kridotomo Yogyakarta. Jurnal Seni Musik, Jurusan Sendratasik, Fakultas Bahasa dan Seni, Universitas Negeri Semarang. 3 (2), p 60-66.

Setiawan, I. (2017). Dokumenter Tv: Udjo \& Saung Angklung sebagai Manifestasi Budaya Sunda. Jurnal Unpad, ProTVF, 1(1), 89-104.

Somawijaya, A. (1995). Angklung Buhun, Sebuah Telusuran Awal (Issue Laporan 
Penelitian).

Sugiyono. (2011). Metode Penelitian Kualitatif Kuantitatif, dan R\&D. Bandung: Alfabeta.

Supriyadi, D. (2006). Model Pembelajaran Angklung Sunda Kreasi di Sanggar Saung Angklung Udjo Ngalagena, Padasuka Bandung Jawa Barat. Jurnal Harmoni Pengetahuan Dan Pemikiran Seni, UNJ, Volume 7, No. 3.

Tim Penyusun Kamus Pusat Bahasa. (2005). Kamus Besar Bahasa Indonesia. Balai Pustaka.

Wiramihardja, O. A. (2010). Panduan Bermain Angklung. Pusat Penelitian dan Pengembangan Kebudayaan Badan Pengembangan Sumber Daya Kebudayaan dan Pariwisata Kementerian Kebudayaan dan Pariwisata.

\section{Informan/Narasumber}

Laretna T. Adishakti (62 tahun). Dosen mata kuliah Seni dan Pusaka di Prodi Tata Kelola Seni Pascasarjana ISI Yogyakarta dan Dosen tetap Universitas Gadjah Mada Yogyakarta.

Eli (34 tahun). Staf Bagian Pemasaran Saung Angklung Udjo Padasuka, Bandung, Jawa Barat.

Nandar (44 tahun). Perajin angklung/pemasok angklung pada Saung Udjo, Padasuka, Bandung, Jawa Barat. 